\title{
Stabilization of $\mathrm{Cu}(\mathrm{I})$ for binding and calorimetric measurements in aqueous solution†
}

\author{
Destinee K. Johnson $^{\mathrm{a}}$, Michael J. Stevenson ${ }^{\mathrm{b}}$, Zayed A. Almadidy ${ }^{\mathrm{a}}$, Sharon E. Jenkins ${ }^{\mathrm{a}}$, \\ Dean. E. Wilcox ${ }^{b}$, and Nicholas E. Grossoehme ${ }^{\star}, a$ \\ aDepartment of Chemistry, Physics and Geology, Winthrop University, Rock Hill, SC 27933, USA.

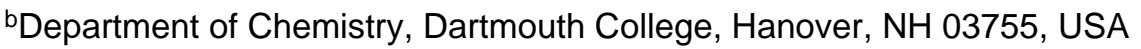

\begin{abstract}
Conditions have been developed for the comproportionation reaction of $\mathrm{Cu}^{2+}$ and copper metal to prepare aqueous solutions of $\mathrm{Cu}^{+}$that are stabilized from disproportionation by $\mathrm{MeCN}$ and other $\mathrm{Cu}^{+}$-stabilizing ligands. These solutions were then used in ITC measurements to quantify the thermodynamics of formation of a set of $\mathrm{Cu}^{+}$complexes $\left(\mathrm{Cu}^{\mathrm{I}}(\mathrm{MeCN})_{3}{ }^{+}, \mathrm{Cu}^{\mathrm{I}} \mathrm{Me}_{6} \mathrm{Trien}^{+}\right.$, $\mathrm{Cu}^{\mathrm{I}}(\mathrm{BCA})_{2}{ }^{3-}, \mathrm{Cu}^{\mathrm{I}}(\mathrm{BCS})_{2}{ }^{3-}$ ), which have stabilities ranging over 15 orders of magnitude, for their use in binding and calorimetric measurements of $\mathrm{Cu}^{+}$interaction with proteins and other biological macromolecules. These complexes were then used to determine the stability and thermodynamics of formation of a $1: 1$ complex of $\mathrm{Cu}^{+}$with the biologically important tri-peptide glutathione, GSH. These results identify $\mathrm{Me}_{6}$ Trien as an attractive $\mathrm{Cu}^{+}$-stabilizing ligand for calorimetric experiments, and suggest that caution should be used with $\mathrm{MeCN}$ to stabilize $\mathrm{Cu}^{+}$due to its potential for participating in unquantifiable ternary interactions.
\end{abstract}

\section{Introduction}

The physiologically relevant oxidation state of copper under reducing conditions, such as that found within cells, is $\mathrm{Cu}^{+} \cdot{ }^{1-3}$ However, the biochemistry of this ion is particularly challenging to study due to its oxidation under aerobic conditions $\left(\Delta G^{\circ}=-414 \mathrm{~kJ} \mathrm{~mol}^{-1}\right)$, its complex chemistry in the presence of halides and oxides, ${ }^{4}$ and its tendency to undergo disproportionation (eqn (1))

$$
2 C u^{+}{ }_{(a q)} \rightleftharpoons C u^{2+}{ }_{(a q)}+C u^{0}(\mathrm{~s})
$$

$\left(K_{\text {disp }}=\left[\mathrm{Cu}^{\mathrm{II}}\right] /\left[\mathrm{Cu}^{\mathrm{I}}\right]^{2} \approx 10^{6}\right)$ in aqueous solution. Further, due to its closed $d$ shell, the cuprous ion lacks many of the spectral signatures of the open $d$ shell cupric ion, limiting several traditional approaches for studying this metal ion. Not only is it diamagnetic and

\footnotetext{
$\dagger$ Electronic supplementary information (ESI) available. See DOI: 10.1039/c5dt02689j * grossoehmen@winthrop.edu.

Author contributions

The first draft of the manuscript was written by NEG with contributions from all authors. ITC and spectrophotometric titrations were conducted by DKJ, SEJ, and NEG at Winthrop University, and MJS at Dartmouth College. Comproportionation reaction analysis was done by ZAA. The idea for this work originated from NEG and DEW.
} 
lacks ligand field transitions, but the charge transfer bands associated with $\mathrm{Cu}^{+}$coordination are normally found in the near-UV and masked by intense protein or DNA absorbance. ${ }^{5,6}$ Therefore, indirect methods are typically used to quantify $\mathrm{Cu}^{+}$binding reactions. For example, competition with bicinchoninic acid (BCA) or bathocuproine disulfonic acid (BCS) is commonly used to determine the affinity of proteins for $\mathrm{Cu}^{+}{ }^{5-12}$ These molecules (Fig. 1) have a large preference for $\mathrm{Cu}^{+}$over $\mathrm{Cu}^{2+}$ and gain intense spectral transitions in the visible region upon $\mathrm{Cu}^{\mathrm{I}}(\mathrm{BCA})_{2}{ }^{3-}$ or $\mathrm{Cu}^{\mathrm{I}}(\mathrm{BCS})_{2}{ }^{3-}$ formation. However, to determine the thermodynamics of $\mathrm{Cu}^{+}$binding to proteins with these ligands would require an indirect van't Hoff analysis.

Isothermal titration calorimetry (ITC), which directly measures heat flow and is not dependent on photophysical properties to determine thermodynamic information, is an attractive technique for studying $\mathrm{Cu}^{+}$binding reactions. ${ }^{13}$ This technique, however, has certain experimental constraints. ${ }^{14}$ Specifically, due to the inherent ability of ITC to detect all of the contributions to the heat that is evolved or consumed during a titration, it is necessary to eliminate or account for all chemical and physical processes that are coupled to the binding event of interest. ${ }^{15}$ This presents a unique challenge when working with $\mathrm{Cu}^{+}$in aqueous solutions due to its inherent instability to oxidation and disproportionation. While oxidation is easily avoided by conducting the experiment under strictly anaerobic conditions, disproportionation occurs independent of $\mathrm{O}_{2}$ and must be suppressed.

The aim of this study was to characterize the thermodynamic properties of $\mathrm{Cu}^{+}$complexes for their use in binding measurements in aqueous solution, particularly those involving ITC. $\mathrm{MeCN}$ was considered initially due to its well-known $\mathrm{Cu}^{+}$complex that has a modest stability. First, conditions for the preparation and stabilization of $\mathrm{Cu}^{+}$by $\mathrm{MeCN}$ in aqueous buffered solutions by a comproportionation reaction (reverse of eqn (1)) were established. Then the thermodynamics of formation of increasingly stable $\mathrm{Cu}^{+}$complexes with $\mathrm{Me}_{6}$ Trien, BCA and BCS were quantified. Finally, the thermodynamics of $\mathrm{Cu}^{+}$interaction with the important cellular thiol glutathione (GSH) were determined. The results from this study indicate that the interaction between $\mathrm{MeCN}$ and $\mathrm{Cu}^{+}$is under estimated in the literature, and enthalpically silent under the experimental conditions used here; further, $\mathrm{MeCN}$ has the potential to form ternary complexes that are difficult to accurately quantify, thereby masking the thermodynamic interactions of interest. We propose $\mathrm{Me}_{6}$ Trien as an alternate stabilizing ligand for $\mathrm{Cu}^{+}$delivery due to its low potential for the formation of ternary complexes. These results provide a foundation for the accurate delivery of aqueous $\mathrm{Cu}^{+}$in measurements of the binding thermodynamics of biological molecules that have a wide range of affinities for this metal ion.

\section{Experimental}

\section{Materials and reagents}

HEPES (4-(2-hydroxyethyl)-1-piperazineethanesulfonic acid), MOPS (3-( $N$ morpholino)propanesulfonic acid), BisTris (2-(bis-(2-hydroxyethyl)amino)-2(hydroxymethyl)propane-1,3-diol) and Tris (2-amino-2-hydroxymethyl-propane-1,3-diol) were obtained from VWR or Sigma, and buffer solutions were prepared using Milli-Q deionized water (>18 M $\Omega$ ). Bathocuproine disulfonate disodium salt (BCS), bicinchoninic 
acid disodium salt hydrate (BCA), 1,1,4,7,10,10-hexamethyltriethylenetetramine ( $\mathrm{Me}_{6}$ Trien), reduced glutathione (GSH), and 5,5'-dithiobis(2-nitrobenzoic acid) (DTNB, Ellman's Reagent) were procured in the highest purity available from Sigma-Aldrich. ACS grade acetonitrile (MeCN) from Sigma-Aldrich was used for all experiments. Copper(II) chloride dehydrate $(99.9 \%+)$ and trace metal grade nitric acid were obtained from Alfa Aesar.

\section{Anaerobic sample preparation}

All reactions were carried out either in a dual chamber CoyLab vinyl glove box with independent chambers for sample preparation and spectral characterization and ITC measurements, which was maintained with $97 \% \mathrm{~N}_{2}$ and $3 \% \mathrm{H}_{2}$ by continuous circulation through the catalyst bed that maintains a consistent $\left[\mathrm{O}_{2}\right]<0.1 \mathrm{ppm}$, or in a single chamber CoyLab rigid plexi-glass glove box maintained with $100 \% \mathrm{~N}_{2}$. Prior to use, all buffer solutions and solvents were thoroughly degassed either by four iterations of a freeze-pumpthaw cycle in Airfree $®$ glassware from Chemglass or by rigorous vacuum degasing followed by extensive purging with pure $\mathrm{N}_{2}$ or Ar.

\section{Spectrophotometry}

Spectrophotometric measurements were carried out in triplicate in the glove box using a Thermo Scientific NanoDrop 2000c operating in cuvette mode. Literature molar extinction coefficients were used for $\mathrm{Cu}^{\mathrm{I}}(\mathrm{BCA})_{2}{ }^{3-}\left(\varepsilon_{563}=7900 \mathrm{M}^{-} \mathrm{cm}^{-1}\right)$ and $\mathrm{Cu}^{\mathrm{I}}(\mathrm{BCS})_{2}{ }^{3-}\left(\varepsilon_{483}=13\right.$ $\left.000 \mathrm{M}^{-1} \mathrm{~cm}^{-1}\right),{ }^{9-11}$ and for 2-nitro-5-thiobenzoic acid $\left(\varepsilon_{412}=14150 \mathrm{M}^{-1} \mathrm{~cm}^{-1}\right),{ }^{16}$ which is the product of DTNB reacting with a free thiol.

\section{Isothermal titration calorimetry (ITC)}

All ITC measurements were carried out in triplicate using either a TA Instruments Nano ITC, housed in the CoyLab vinyl glove box, with a $170 \mu \mathrm{L}$ sample cell, a $50 \mu \mathrm{L}$ titration syringe, 1-2.5 $\mu \mathrm{L}$ injection volumes and 240-1200 second intervals between injections, as dictated by the experiment, or a Micro-Cal VP-ITC, housed in a custom anaerobic plexiglass glove box, with a $1.4 \mathrm{~mL}$ sample cell, a $300 \mu \mathrm{L}$ titration syringe, 6-10 $\mu \mathrm{L}$ injection volumes and 600-1200 second intervals between injections. Note, the TA Instruments Nano ITC data are plotted with positive exothermic heat flow, while the MicroCal VP-ITC data are plotted with negative exothermic heat flow. In the figures of ITC measurements, the top panel shows the raw ITC data (power $v s$. time), where each spike represents the injection of titrant into the cell, and the bottom panel shows the integrated and normalized heat plotted $v s$. the molar ratio of titrant (syringe) to titrand (cell). The Residual Sum of Squares per Degree of Freedom (RSS/DoF) is reported as a measure of the goodness of fit. Prior to ITC titrations, the BCS and BCA concentrations were verified spectrophotometrically with excess $\mathrm{Cu}^{+}$, using the extinction coefficients listed above, and the concentration of reduced thiol in solutions of GSH was measured using the standard DTNB assay. ${ }^{16}$

Data were fit using the TA NanoAnalyze, Origin or SEDPHAT ${ }^{17}$ packages. The one-site model assumes $n$ binding "sites", each with identical binding properties, while the sequential model assumes that two or more complexes are formed in sequence (i.e., the ML complex must form prior to the $\mathrm{ML}_{2}$ complex, where $\mathrm{M}=$ metal and $\mathrm{L}=$ ligand). Integer 
stoichiometry units are required for the sequential model. The overall equilibrium is defined by the standard $\beta_{n}$ nomenclature, where $\beta_{n}=\frac{\left[M L_{n}\right]}{[\mathrm{M}][\mathrm{L}]^{n}}$.

In most cases, the error was calculated from the standard deviation of two or more titrations. When fitting GSH titration data in HEPES buffer to a sequential binding model, the standard deviation did not accurately reflect the error associated with the $2^{\text {nd }}$ binding event. In this case, the reported error was calculated by error propagation from three independent titrations.

\section{Comproportionation reaction}

The comproportionation reactions were carried out anaerobically using copper wire that had been incubated in ethylene-diaminetetraacetate (EDTA) for 2 hours to ensure the surface was free of metal ion contaminants. The wire was then washed 3-5 times in Milli-Q water to remove the EDTA and air dried prior to use. For the quantitative reactions, $1.00 \pm 0.03 \mathrm{~g}$ pieces of the clean dry wire were cut and taken into the glove box; non-quantitative reactions used pieces that were $\sim 5 \mathrm{~cm}$ in length. Reactions were set up in the glove box and incubated using a Thermo Scientific Labquake ${ }^{\circledR}$ Rotisserie rotator.

\section{Metal analysis}

The copper concentration was determined with two independent methods. The total soluble copper $\left(\mathrm{Cu}^{+}+\mathrm{Cu}^{2+}\right)$ was measured using a Perkin Elmer 560 Atomic Absorbance Spectrometer (AAS) with standards in the $0.5-5.0 \mathrm{ppm}$ range $\left(r^{2}>0.997\right)$. Average values were determined from a minimum of three measurements. The cuprous ion concentration was measured by adding a large excess of BCA in $25 \mathrm{mM}$ MOPS, $\mathrm{pH} 6.0$, and measuring the absorption at $563 \mathrm{~nm}\left(\mathrm{Cu}^{\mathrm{I}}(\mathrm{BCA})_{2}{ }^{3-} ; \varepsilon_{563}=7900 \mathrm{M}^{-1} \mathrm{~cm}^{-1}\right)$. This $\mathrm{pH}$ was selected to minimize the hydroxide-mediated reduction of $\mathrm{Cu}^{2+}$ to $\mathrm{Cu}^{+}$in the presence of BCA (unpublished results).

\section{Coupled equilibrium calculations}

The analysis to account for speciation (metal-ligand and proton) during ITC experiments is described elsewhere in detail. ${ }^{15,18,19}$ Briefly, competition factors are calculated according to:

$$
Q=\sum_{n=0}^{x}\left(\beta_{n}[\mathrm{X}]^{n}\right)
$$

where $Q$ is the competition factor (typically called $a$ what the competition comes from protons), $\beta_{n}$ is the $n^{\text {th }}$ overall affinity constant and $\mathrm{X}$ is the competing ligand (for metal competition) or proton (for $\mathrm{pH}$ corrections). The observed equilibrium constant is readily corrected by

$$
K=K_{I T C} Q
$$


A combination of eqn (2) and (3) was used to determine the $\mathrm{pH}$-independent formation constant for $\mathrm{Cu}^{\mathrm{I}} \mathrm{Me}_{6}$ Trien $^{+}$from $\mathrm{Me}_{6}$ Trien displacement by BCA or BCS. A sample calculation is reported in the ESI. $\dagger$

$$
K_{C u-B C A}=K_{I T C}\left(1+\frac{\left[M e_{6} \text { Trien }\right]_{\text {total }}}{\alpha} K_{C u M e_{6} T r i e n}\right)
$$

\section{Electron paramagnetic resonance (EPR)}

The EPR spectra were recorded at $77 \mathrm{~K}$ on a Bruker EMX $300 \mathrm{X}$-band EPR spectrometer (Bruker Biosciences Corp.) using five signal-averaged scans with the following conditions: 9.68 GHz microwave frequency, $5.02 \mathrm{~mW}$ microwave power, $100 \mathrm{kHz}$ modulation frequency, $5.00 \mathrm{G}$ modulation amplitude and $81.92 \mathrm{~ms}$ time constant. Samples were prepared in gas tight quartz tubes by diluting a $50 \mathrm{mM} \mathrm{Cu}{ }^{+}$comproportionation reaction stock in $\mathrm{MeCN}$. All samples were stored at $-80{ }^{\circ} \mathrm{C}$ before the measurement.

\section{Results and discussion}

\section{Acetonitrile}

Preparation and characterization of $\mathrm{Cu}^{+}$aq stabilized by $\mathrm{MeCN}-$ Acetonitrile is often used to stabilize $\mathrm{Cu}^{+}$as the $\mathrm{Cu}^{\mathrm{I}}(\mathrm{MeCN})_{4}{ }^{+}$complex; ${ }^{20}$ indeed, anaerobic dissolution of $\mathrm{Cu}(\mathrm{MeCN})_{4}^{+}$salts in neat $\mathrm{MeCN}$ is an established procedure for storing $\mathrm{Cu}^{+}$and these solutions are used for biochemistry experiments involving this ion. In our hands, however, dilution of these $\mathrm{MeCN}$ solutions in some aqueous buffers resulted in visible precipitation of $\mathrm{Cu}^{+}$species. As an alternate approach, we evaluated the comproportionation reaction of $\mathrm{CuCl}_{2}$ with copper metal in the presence of excess $\mathrm{MeCN}$ to produce aqueous solutions of $\mathrm{MeCN}$-stabilized $\mathrm{Cu}^{+}$. This approach inherently removes residual oxygen because any $\mathrm{Cu}^{2+}$ produced by oxidation will be readily converted back to $\mathrm{Cu}^{+}$; further, the cuprous ion is now in equilibrium with the aqueous conditions and other solutes (e.g., chloride). In addition, this approach is easily adapted for the preparation of solutions with $\mathrm{Cu}^{+}$stabilized by other ligands, as demonstrated later with $\mathrm{Me}_{6}$ Trien.

One $\mathrm{mL}$ solutions containing $25.00 \mathrm{mM} \mathrm{CuCl}_{2}$ and $1.00 \mathrm{~g}$ clean copper wire (see Experimental for details) were incubated with increasing concentrations of $\mathrm{MeCN}$ under strictly anaerobic conditions. Reaction progress was monitored by the analysis of withdrawn aliquots with two methods: (a) atomic absorbance spectroscopy (Fig. 2A), and (b) addition of excess BCA and measurement of $\mathrm{Abs}_{563}$, the characteristic wavelength of the $\mathrm{Cu}^{\mathrm{I}}(\mathrm{BCA})_{2}{ }^{3-}$ complex (Fig. 2B). These complementary methods provide a measure of the total soluble copper and $\left[\mathrm{Cu}^{+}\right]$, respectively; the former should start at $25 \mathrm{mM}$ (initial $\left[\mathrm{Cu}^{2+}\right]$ ) and progress to $50 \mathrm{mM}$, while the latter should begin at $0 \mathrm{mM}$ and build to $50 \mathrm{mM}$ because the BCA assay is specific for $\mathrm{Cu}^{+}$. The data from the two methods mirror each other, with only minor deviations. The extent of the reaction scales with [MeCN]; while the lower concentrations of $\mathrm{MeCN}(250$ and $500 \mathrm{mM})$ stabilize some $\mathrm{Cu}^{+}$, they are not sufficient to drive the reaction to completion, even after many hours. The higher $\mathrm{MeCN}$ concentrations $(1,2$, and $4 \mathrm{M})$ successfully convert all of the $\mathrm{Cu}^{2+}$ to $\mathrm{Cu}^{+}$. Based on these results, all comproportionation reactions were carried out with $1 \mathrm{M} \mathrm{MeCN}$ and $25 \mathrm{mM} \mathrm{Cu}^{2+}$ 
for at least 3 hours. The final solution was stored in the glove box in a sealed plastic test tube containing a small piece of copper wire. This solution remained colorless and periodic testing by AAS indicated negligible change in the total soluble copper over a 6-month period.

Since oxidation or disproportionation of the cuprous ion will yield $\mathrm{Cu}^{2+}$, electron paramagnetic resonance (EPR) was used to quantify $\mathrm{Cu}^{2+}$ and thereby determine the $\mathrm{MeCN}$ concentration required to stabilize $\mathrm{Cu}^{+}$in aqueous solutions used for titration experiments. The $50 \mathrm{mM}$ stock $\mathrm{Cu}^{+}$solution in $1 \mathrm{M} \mathrm{MeCN}$ was diluted to $125 \mu \mathrm{M} \mathrm{Cu}^{+}$in 5 and $25 \mathrm{mM}$ $\mathrm{MeCN}$ and transferred to gas tight EPR tubes for measurements at $77 \mathrm{~K}$; the spectra of these solutions were then compared to those of 12.5 and $1.25 \mu \mathrm{M} \mathrm{Cu}^{2+}$ standards, which contain $10 \%$ and $1 \%$ of the copper in the experimental samples, respectively (Fig. 3). No $\mathrm{Cu}^{2+}$ EPR signal was detectable in the $\mathrm{Cu}^{+}$sample with $25 \mathrm{mM} \mathrm{MeCN}$, even when the gain was increased by 10 . The $\mathrm{Cu}^{+}$sample with $5 \mathrm{mM} \mathrm{MeCN}$ has a signal indicating the presence of $\sim 4-5 \mu \mathrm{M} \mathrm{Cu}^{2+}$, based on peak intensity. Its origin from oxidation is unlikely since $\mathrm{Cu}^{2+}$ was not observed in the identically handled $25 \mathrm{mM} \mathrm{MeCN}$ sample. Therefore, the source of the oxidized copper is believed to be disproportionation; indeed, a BCA assay of a sample under these conditions indicates that $\left[\mathrm{Cu}^{+}\right]$is $85 \%$ of the expected value. Based on these results, the final $[\mathrm{MeCN}]$ was never less than $25 \mathrm{mM}$ and the $[\mathrm{MeCN}] /\left[\mathrm{Cu}^{+}\right]$ratio was maintained at $>40$, as established in the comproportionation reaction with $1 \mathrm{M} \mathrm{MeCN}$.

MeCN stabilization of $\mathrm{Cu}^{+}{ }_{(\mathrm{aq})}$-Data in Fig. 2 confirm that acetonitrile at high concentration $(>1 \mathrm{M})$ is able to rapidly and completely produce $50 \mathrm{mM} \mathrm{Cu}^{+}$from $25 \mathrm{mM}$ $\mathrm{Cu}^{2+}$ and $\mathrm{Cu}^{0}$ through a comproportionation reaction in aqueous solution. Oxidation of $\mathrm{Cu}^{+}$ is prevented by preparation and storage under strictly anaerobic conditions, and $\left[\mathrm{Cu}^{+}\right]$does not change over at least 6 months. EPR spectroscopy of experimental solutions indicates that $5 \mathrm{mM} \mathrm{MeCN}$ is not sufficient to stabilize $125 \mu \mathrm{M} \mathrm{Cu}^{+}$but $25 \mathrm{mM} \mathrm{MeCN}$ maintains $>99.5 \%$ $\mathrm{Cu}^{+}$.

The $\mathrm{Cu}^{+}-\mathrm{MeCN}$ equilibrium constants reported by Kamau and Jordan ${ }^{20}$ predict a small amount of uncomplexed $\mathrm{Cu}^{+}$under the solution conditions used in this study (ESI Table $\mathrm{S} 1 \dagger)$, in which case the equilibrium would gradually shift away from $\mathrm{Cu}^{+}$due to disproportionation. This is not consistent with our observation that $125 \mu \mathrm{M} \mathrm{Cu}^{+}$is stable for days in $25 \mathrm{mM} \mathrm{MeCN}$. Further, using their values in the analysis of our BCA titrations into MeCN-stabilized $\mathrm{Cu}^{+}$(vide infra) gives a condition-independent $\log \beta_{2}=15.2$ for $\mathrm{Cu}^{\mathrm{I}}(\mathrm{BCA})_{2}{ }^{+}$, which is two orders of magnitude smaller than the values reported by Wedd 9 and Fahrni. ${ }^{21}$ While this may be due to different solution conditions, it is noteworthy that the most likely culprit, chloride, which may be interacting with $\mathrm{Cu}^{+}$under the experimental conditions, has a negligible effect on the thermodynamics of $\mathrm{Cu}^{\mathrm{I}}(\mathrm{BCA}){ }_{2}{ }^{3-}$ formation over a 1000 -fold range of concentration ( $<0.1 \mathrm{mM}-100 \mathrm{mM} \mathrm{NaCl}$; ESI Table S2 $\dagger$ ). The ambiguity in the $\mathrm{MeCN}$ values is reinforced by noting that the NIST value ${ }^{22}$ for $\beta_{2}$ is $12 \%$ higher than the Kamau and Jordan value. ${ }^{20}$ Thus, the published $\mathrm{Cu}^{+}-\mathrm{MeCN}$ affinity constants should be used with caution.

As an alternate approach, the well accepted $\beta_{2}$ value $\left(3.16 \times 10^{17}\right)^{9,21}$ for the formation of $\mathrm{Cu}^{\mathrm{I}}(\mathrm{BCA})_{2}{ }^{3-}$ can be used to quantify the $\mathrm{MeCN}$ competition for $\mathrm{Cu}^{+}(Q$ in eqn (2) and (3)), 
and thus its interaction with the metal ion, under the experimental conditions. Using this approach, we determined the average value of $Q=65000 \pm 5000\left(K=\beta_{2}=3.16 \times 10^{17}\right.$ in eqn (3)). This value accounts for all the competition with BCA for the $\mathrm{Cu}^{+}$under these conditions including, but not limited to, $\mathrm{MeCN}$, buffer, and $\mathrm{Cl}^{-}$. To test this approach, the condition-independent $\beta_{2}$ value for the formation of $\mathrm{Cu}^{\mathrm{I}}(\mathrm{BCS})_{2}{ }^{3-}$ was calculated from the average best fit experimental value for $\mathrm{BCS} \rightarrow \mathrm{Cu}^{+}$titrations in $25 \mathrm{mM} \mathrm{MeCN}$ (vide infra) using this value of $\mathrm{Q}$; this leads to $\log \beta_{2}=20.6 \pm 0.1$, which is reassuringly bracketed by the values reported by Wedd (19.9) ${ }^{9}$ and Fahrni (20.8). ${ }^{21}$

$\mathrm{Cu}^{+}-\mathrm{MeCN}$ enthalpy-One of the main advantages of ITC is its ability to directly measure the enthalpy of binding reactions. For measurements of metal ions binding to proteins, the experimental enthalpy necessarily includes contributions from metal-ligand and metal-buffer interactions, which must be included in a post hoc analysis of the data to accurately quantify the metal-protein interactions. The aqueous solution chemistry of $\mathrm{Cu}^{+}$ prevents the direct measurement of $\mathrm{Cu}^{+}-\mathrm{MeCN}$ interactions by ITC; however, the enthalpy of this interaction can be estimated by systematically varying $[\mathrm{MeCN}]$ and observing the effect on the enthalpy of $\mathrm{BCA} \rightarrow \mathrm{Cu}^{+}$titrations. ESI Table $\mathrm{S} 1 \uparrow$ reports the distribution of $\mathrm{Cu}^{+}-\mathrm{MeCN}$ species at $10,25,500$, and $1000 \mathrm{mM} \mathrm{MeCN}$, for which there is likely a modest error due to uncertainty in the stability constants, discussed above. These calculated values indicate that the average number of coordinated MeCN's ranges from $1.0\left(68 \% \mathrm{Cu}^{\mathrm{I}}(\mathrm{MeCN})\right.$ and $\left.16 \% \mathrm{Cu}^{\mathrm{I}}(\mathrm{MeCN})_{2}\right)$ at $10 \mathrm{mM}$ up to $2.6\left(1 \% \mathrm{Cu}^{\mathrm{I}}(\mathrm{MeCN}), 40 \% \mathrm{Cu}^{\mathrm{I}}(\mathrm{MeCN})_{2}\right.$ and $59 \%$ $\left.\mathrm{Cu}^{\mathrm{I}}(\mathrm{MeCN})_{3}\right)$ at $1000 \mathrm{mM}$. Strikingly, the reaction enthalpy for $\mathrm{BCA} \rightarrow \mathrm{Cu}^{+}$titrations is not sensitive to $[\mathrm{MeCN}]$ over this range. This suggests that the enthalpy of $\mathrm{Cu}^{\mathrm{I}}(\mathrm{MeCN})_{n}$ complex dissociation is within the error of this experiment (standard error $=0.23 \mathrm{~kJ} \mathrm{~mol}^{-1}$ ). Based on these results, $\mathrm{Cu}-\mathrm{MeCN}$ interactions under these conditions ( $25 \mathrm{mM}$ Tris $\mathrm{pH} 8.0$, $25^{\circ} \mathrm{C}$ ) are entropically driven and have an estimated enthalpy of only $0.00 \pm 0.23 \mathrm{~kJ} \mathrm{~mol}^{-1}$. Entropy-driven metal ligation is a well-documented phenomenon, whose origin is the displacement of the highly ordered solvent shell around the hydrated metal ion. ${ }^{23}$

\section{$B C A$ and BCS}

BCA-Cu+ interaction-BCA forms a well-known $2: 1$ complex with $\mathrm{Cu}^{+}$that is readily monitored by spectroscopic methods, making it easy to measure the concentration of this complex. Therefore, it was chosen to test $\mathrm{MeCN}$ stabilization of $\mathrm{Cu}^{+}$for calorimetric measurements. The ITC data for BCA $\rightarrow \mathrm{Cu}^{+}$titrations in HEPES buffer at $\mathrm{pH} 7.0$ show a sigmoidal titration curve with a major inflection at a $2: 1 \mathrm{BCA}: \mathrm{Cu}^{+}$ratio (Fig. 4). These data can be sufficiently fit using a one-site binding model with $n=2$ (fit values summarized in Table 1), indicating that the two binding events have equivalent thermodynamic properties. Fitting the data to a sequential binding model provides a slightly better fit, according to a residual sum of squares analysis per degree of freedom $\left(\mathrm{RSS} / \mathrm{DoF}_{\text {onesite }}=\right.$ $\left.7.71 v s . \mathrm{RSS} / \mathrm{DoF}_{\text {sequential }}=4.04\right)$. The major difference between these two fits is the somewhat more exothermic $\Delta H_{1}$ value in the sequential model than in the one-site model.

To test which model most accurately reflects the $\mathrm{BCA} / \mathrm{Cu}^{+}$binding chemistry, a reverse titration $\left(\mathrm{Cu}^{+} \rightarrow \mathrm{BCA}\right)$ was carried out under the same conditions. In this titration, $\mathrm{BCA}$ is in excess at the beginning of the titration, so the $\mathrm{Cu}^{\mathrm{I}}(\mathrm{BCA})_{2}{ }^{3-}$ complex forms in the first 
injections. Indeed, the best fit to these data gives an enthalpy that is twice that of the BCA $\rightarrow \mathrm{Cu}^{+}$titration $\left(\Delta H_{\mathrm{obs}}=-72 \mathrm{~kJ} \mathrm{~mol}^{-1}\right)$, and no evidence of a second binding event is observed (ESI Fig. S1 $\dagger$ ). This result is consistent with the one-site model, which predicts two equivalent $\mathrm{BCA}$ binding events; as additional $\mathrm{Cu}^{+}$is added to the $\mathrm{Cu}^{\mathrm{I}}(\mathrm{BCA})_{2}{ }^{3-}$ complex at stoichiometries of $n>0.5$, the shift to two $\mathrm{Cu}^{\mathrm{I}}(\mathrm{BCA})_{1}{ }^{1-}$ complexes would result in a net $\Delta H_{\mathrm{obs}}=0$ (Scheme 1). Further, a global analysis of the forward and reverse titrations using SEDPHAT results in nearly identical parameters for each event.

To verify these results, analogous measurements were made in Tris buffer at $\mathrm{pH} 8.0$ and similar qualitative results were observed. However, the best fit of these $\mathrm{BCA} \rightarrow \mathrm{Cu}^{+}$ titrations with a one-site model yields $\Delta H=-27 \mathrm{~kJ} \mathrm{~mol}^{-1}$, which is $10 \mathrm{~kJ} \mathrm{~mol}^{-1}$ less exothermic than the same titration in HEPES buffer at pH 7.0 (Table 1). Since BCA lacks an ionizable proton in this $\mathrm{pH}$ range, it is unlikely that coupled proton flow is responsible for the difference, suggesting an alternate reason for the enthalpy difference. One difference between Tris and HEPES is the primary amine of the former and the tertiary amine of the latter (Fig. 1); this suggests that Tris may be able to compete with $\mathrm{MeCN}$ and coordinate the $\mathrm{Cu}^{+}$while HEPES may not for steric reasons. To test this hypothesis, the same titration was carried out at pH 6.0 and 7.0 in BisTris buffer, which also has a tertiary amine. In both cases, the one-site fit values (Table 1) are essentially identical to those obtained in HEPES. Further, titrations in Tris at $\mathrm{pH} 7.5$ and 8.5 give thermodynamic values that are similar to those observed at $\mathrm{pH} 8.0$ (Table 1). However, a modest trend is observed in the stability, as a three-fold higher affinity is found at $\mathrm{pH} 7.5$ relative to $8.5\left(2.2 \times 10^{6}\right.$ and $0.8 \times 10^{6}$, respectively). This observation is consistent with the basic form of the Tris primary amine competing for one of the metal coordination sites, although this trend does not show up in the binding enthalpy.

BCS- $\mathrm{Cu}^{+}$interaction-BCS has been an important tool in studies of the $\mathrm{Cu}^{+}$affinity of cuproproteins, ${ }^{5-12}$ and it is important to determine the thermodynamics of formation of the $\mathrm{Cu}^{\mathrm{I}}(\mathrm{BCS})_{2}{ }^{3-}$ complex. Fig. 5 shows a representative ITC titration of BCS into $\mathrm{Cu}^{+}$ stabilized by $\mathrm{MeCN}$. The raw data (top panel) have a much slower return to baseline per injection than observed with other ligands; in fact, 20 minutes is required to completely finish the heat evolution of injections near the inflection point (see inset of Fig. 5). The data show a slow progression toward increasingly exothermic injections until a steep inflection is observed at $2: 1$, bringing the injection heat back to the baseline. While these data provide an accurate measure of the binding enthalpy, the binding constant determined from the steep inflection would have considerable uncertainty. Nevertheless, these data were fit to obtain $K$ values for later comparison to stabilities that can be accurately determined.

Table 2 summarizes the average fits using two different binding models. A one-site binding model provides a reasonably good fit of the data at the beginning of the titration, especially considering the scatter in these points, but fails to accurately capture the steepness of the inflection at $2: 1$, resulting in an underestimation of $K$. The other two fit lines in Fig. 5 (red and blue) represent two different fits (local minima) that consistently converge using a sequential binding model. The blue line more accurately captures the inflection observed at the $1: 1$ molar ratio but fails to reflect the steepness of the inflection at the $2: 1$ ratio. In contrast, the red line is biased toward the steep $2: 1$ inflection and does not recognize the 
'step' at $1: 1$. The blue fit is somewhat better, according to a residual sum of squares analysis $\left(\mathrm{RSS} / \mathrm{DoF}_{\text {blue }}=50.5\right.$ and $\left.\mathrm{RSS} / \mathrm{DoF}_{\text {red }}=67.75\right)$; however, this is largely due to the number of data points leading up to the major $2: 1$ inflection, and it fails to account for the poor fit of the major inflection. As such, the red model appears to be the more physically appropriate, and the data in Table 2 reflect this fit.

BCA and BCS stabilization of $\mathrm{Cu}^{+}{ }_{(\mathrm{aq})}$ - Both BCA and BCS are nitrogenous bidentate ligands that are selective for $\mathrm{Cu}^{+}$over $\mathrm{Cu}^{2+}$ due to their firm requirement for a tetrahedral coordination geometry. ${ }^{24,25}$ As summarized in Table 3, these two ligands form very stable $2: 1 \mathrm{Cu}^{+}$complexes $\left(\beta_{2, \mathrm{BCA}}=10^{17.7}\right.$ and $\left.\beta_{2, \mathrm{BCS}}=10^{20.6}\right)$ with the indicated enthalpies of formation. Their free energies of formation are $\Delta G_{\mathrm{BCA}}=-101 \mathrm{~kJ} \mathrm{~mol}^{-1}$ and $\Delta G_{\mathrm{BCS}}=-118$ $\mathrm{kJ} \mathrm{mol}^{-1}$, respectively, and Fig. 6 depicts the overall thermodynamic profiles for BCA and BCS binding to $\mathrm{Cu}^{+}$. The difference between their free energies of formation $(\Delta \Delta G=-16 \mathrm{~kJ}$ $\left.\mathrm{mol}^{-1}\right)$ is predominantly due to the difference between their formation enthalpies $(\Delta \Delta H=$ $-19 \mathrm{~kJ} \mathrm{~mol}^{-1}$ ), indicating that the change in entropy for BCA and BCS binding to $\mathrm{Cu}^{+}$is similar $\left(-T \Delta S=-34 \mathrm{~kJ} \mathrm{~mol}^{-1}\right)$. This enthalpic difference is consistent with the fact that the BCS nitrogens are stronger Lewis bases than the BCA nitrogens, as indicated by the measurable $\mathrm{p} K_{\mathrm{a}}$ (5.7) of BCS but not BCA. ${ }^{9}$ The thermo- dynamics of the two sequential binding events for BCA are identical but this is not so for BCS, as the first coordination has a favorable entropic contribution, while the second does not (ESI Table S3†). However, without information about the intermediate $\mathrm{Cu}(\mathrm{BCS})_{1}(\mathrm{MeCN})_{x}{ }^{-1}$ species, the source of this thermodynamic difference cannot be determined.

The binding of BCS to $\mathrm{Cu}^{+}$was uniquely slow among the ligands in this study. The long time required to return to baseline, especially near the $2: 1$ equivalence point where the concentration of $\mathrm{MeCN}$-stabilized $\mathrm{Cu}^{+}$is low (Fig. 5, inset), indicates slow ligand exchange kinetics for BCS. This contrasts with the observation that spectrophotometric titrations with BCS show no indication of slow kinetics (data not shown). It is possible that spectroscopically-observable binding events occur quickly and the slower heat evolution is due to a spectroscopically-unobservable rearrangement around the metal. Whatever the reason, this should be considered when designing experiments using this ligand for thermodynamic or kinetic studies.

\section{$\mathrm{Me}_{6}$ Trien}

$\mathrm{Me}_{6}$ Trien-Cu+ $\mathrm{Cu}^{+}$interaction-Since $\mathrm{MeCN}$ stabilizes $\mathrm{Cu}^{+}$with a relatively low overall stability and the $2: 1 \mathrm{Cu}^{+}$complexes with BCA and BCS are very stable, there is a need for a well-characterized $\mathrm{Cu}^{+}$complex with intermediate stability. Such a complex is found with the tetradentate ligand hexamethyltriethylenetetramine, $\mathrm{Me}_{6}$ Trien, where the methyl groups enforce a $\mathrm{Cu}^{+}$-favoring tetrahedral coordination. ${ }^{26,27}$ Initially we attempted to quantify the formation thermodynamics of $\mathrm{Cu}^{\mathrm{I}}\left(\mathrm{Me}_{6} \text { Trien }\right)^{+}$by ITC titrations with $\mathrm{MeCN}$-stabilized $\mathrm{Cu}^{+}$ solutions, as we did with BCA and BCS. However, the large excess of MeCN required to stabilize $\mathrm{Cu}^{+}$and the proton competition with $\mathrm{Cu}^{+}$for $\mathrm{Me}_{6} \operatorname{Trien}\left(\mathrm{p} K_{\mathrm{a} 1}=9.19, \mathrm{p} K_{\mathrm{a} 2}=8.38\right.$, $a=651)^{22}$ at $\mathrm{pH} 7.4$ led to immeasurable formation under these conditions. Therefore, we prepared the $\mathrm{Cu}^{\mathrm{I}}\left(\mathrm{Me}_{6} \text { Trien }\right)^{+}$complex by comproportionation, ${ }^{26}$ as described for $\mathrm{MeCN}$, and measured $\mathrm{Me}_{6}$ Trien displacement by ligands with higher $\mathrm{Cu}^{+}$affinity. Since this 
complex is more stable than the MeCN complex, only a 5-6 fold excess of $\mathrm{Me}_{6}$ Trien was necessary for the comproportionation, and a successful synthesis was indicated by complete

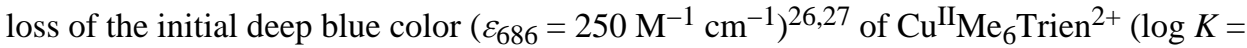
$12.60, \varepsilon^{\circ}=60 \mathrm{mV}$ at $\left.\mathrm{pH} 7.0\right) .{ }^{27}$ Since experimental titrations that deliver $\mathrm{Cu}^{+}$as the $\mathrm{Cu}^{\mathrm{I}} \mathrm{Me}_{6}$ Trien $^{+}$complex necessarily involve the displacement of $\mathrm{Me}_{6}$ Trien by another ligand or a protein, a sufficient excess ( $>50$ fold) of $\mathrm{Me}_{6}$ Trien in the titrant and titrand solutions ensures a relatively constant concentration over the course of the titration for a simplified binding analysis. This larger excess is recommended for the comproportionation preparation of $\mathrm{Cu}^{\mathrm{I}} \mathrm{Me}_{6}$ Trien $^{+}$as well.

Representative ITC data for a BCA titration of $\mathrm{Cu}^{\mathrm{I}} \mathrm{Me}_{6} \mathrm{Trien}^{+}$(Fig. 7a) show the expected $2: 1$ binding stoichiometry and the data can be reasonably fit to a one-site binding model, indicating either cooperative binding of both BCA ligands or similar enthalpies for each one binding to the $\mathrm{Cu}^{+}$. A reverse titration gives a single inflection at $n=0.5$ and twice the enthalpy, indicating that the latter is the correct interpretation, as found for BCA titrations with $\mathrm{MeCN}$-stabilized $\mathrm{Cu}^{+}$. Similar results (Fig. 7b), and a similar interpretation, are found for BCS titrations of $\mathrm{Cu}^{\mathrm{I}} \mathrm{Me}_{6} \mathrm{Trien}^{+}$. Table 4 contains the average best-fit experimental values for the BCA and BCS titrations of $\mathrm{Cu}^{\mathrm{I}} \mathrm{Me}_{6}$ Trien $^{+}$.

$\mathrm{Me}_{6}$ Trien stabilization of $\mathrm{Cu}_{(}^{+}{ }_{(\mathrm{aq})}$-These results have shown that $\mathrm{Me}_{6}$ Trien can be used as a ligand for $\mathrm{Cu}^{+}$delivery from a complex that is more stable than those with $\mathrm{MeCN}$ and avoids ternary intermediates. Comproportionation preparation of this species is shown by the complete conversion of $\mathrm{Cu}^{\mathrm{II}} \mathrm{Me}_{6} \mathrm{Trien}^{2+}$ to $\mathrm{Cu}^{\mathrm{I}} \mathrm{Me}_{6}$ Trien $^{+}$. Analysis of the data in Table 4 that takes into account the stability and enthalpy of formation of $\mathrm{Cu}^{\mathrm{I}}(\mathrm{BCA})_{2}{ }^{3-}$, or analogous values for $\mathrm{Cu}^{\mathrm{I}}(\mathrm{BCS})_{2}{ }^{3-}$, as well as the $\mathrm{p} K_{\mathrm{a}}$ 's and protonation enthalpies of $\mathrm{Me}_{6}$ Trien and the buffer, ${ }^{22}$ leads to the buffer-independent stability constant and enthalpy of formation of $\mathrm{Cu}^{\mathrm{I}} \mathrm{MeTrien}^{+}$(Table 3). In contrast to solutions of $\mathrm{MeCN}$-stabilized $\mathrm{Cu}^{+}$, binding studies that use this complex to deliver $\mathrm{Cu}^{+}$will depend on the $\mathrm{pH}$ and are somewhat more complicated to analyze due to the higher basicity of this ligand (representative calculations are found in the ESI $\dagger$ ). A somewhat lower precision in the $\mathrm{Cu}^{\mathrm{I}} \mathrm{MeTrien}^{+}$heat of formation is due to uncertainties in the heats of $\mathrm{Me}_{6}$ Trien protonation $^{22}$ and a small discrepancy between the BCA and BCS titrations.

However, the $\mathrm{Cu}^{\mathrm{I}} \mathrm{MeTrien}^{+}$stability $\left(K=10^{12.4}\right.$ at $\mathrm{pH}$ 7.4) bridges the gap between that of $\mathrm{Cu}^{\mathrm{I}}(\mathrm{MeCN})_{3}{ }^{+}\left(\beta_{3}=10^{4.3}\right)$ and $\mathrm{Cu}^{\mathrm{I}}(\mathrm{BCA})_{2}{ }^{3-}\left(\beta_{2}=10^{17.5}\right.$.

\section{Buffers}

$\mathrm{Cu}^{+}$-buffer interactions-Throughout this work, three experimental buffers have been used to assess the applicability of these $\mathrm{Cu}^{+}$-stabilizing complexes under a variety of experimental conditions. To test the effects of $\mathrm{pH}$ and the buffer, BCA titration data (Table 1) were used, since its interaction with $\mathrm{Cu}^{+}$is independent of $\mathrm{pH} .{ }^{9}$ No significant differences were observed when the $\mathrm{pH}$ was changed from 6.0 to 7.0 with BisTris or when the buffer was changed to HEPES at $\mathrm{pH} 7.0$. However, a difference of $10 \pm 1 \mathrm{~kJ} \mathrm{~mol}^{-1}$ in the binding enthalpy was found when the buffer was changed to Tris at $\mathrm{pH} 7.5,8.0$, and 8.5, indicating that Tris is interacting with the $\mathrm{Cu}^{+}-\mathrm{MeCN}$ complex(es) and must be displaced. HEPES and 
BisTris both have an exchangeable proton on a tertiary amine, while the protonation site of Tris is a primary amine that is more accessible to coordinate to a metal (Fig. 1). The modest increase in the observed binding constant with decreasing $\mathrm{pH}\left(K_{8.5}=0.8 \times 10^{6}, K_{8.0}=2.0 \times\right.$ $10^{6}, K_{7.5}=2.2 \times 10^{6}$ ) in Tris is consistent with this hypothesis; as the solution becomes more acidic, the fraction of the basic form of Tris that is able to compete for the $\mathrm{Cu}^{+}$ decreases. However, any accompanying change in the binding enthalpy is within the error of the measurement, and this interaction with Tris does not shift the disproportionation equilibrium away from $\mathrm{Cu}^{+}$under these experimental conditions. Further support for this interpretation of Tris effects on the $\mathrm{Cu}^{+}$binding thermodynamics is found with preliminary BCA titrations of $\mathrm{Cu}^{\mathrm{I}} \mathrm{Me}_{6} \mathrm{Trien}^{+}$in the primary amine buffer ACES.

\section{Glutathione}

Glutathione- $\mathrm{Cu}^{+}$interaction-Since GSH is the most abundant cytoplasmic thiol in most cells and is reported to have a high affinity for $\mathrm{Cu}^{+}, 28$ it is important to accurately determine the thermodynamics of GSH binding to $\mathrm{Cu}^{+}$. This was investigated with $\mathrm{MeCN}-$ stabilized $\mathrm{Cu}^{+}$in Tris at $\mathrm{pH} 8.0$ and HEPES at $\mathrm{pH}$ 7.5. Fig. 8 shows representative ITC data for the latter and the heat of GSH dilution. In this case, the $\mathrm{GSH} \rightarrow \mathrm{Cu}^{+}$titration fails to reach the baseline established by the dilution titration. This is most likely due to a second binding event with low affinity and/or low heat that occurs subsequent to formation of the $1: 1$ complex. Fitting the data to a one-site binding model (black line) provides a reasonable fit with $n=1$. However, this model cannot account for the small amount of heat that follows the inflection. All the data can be well fit to a sequential binding model (red line), although large errors are associated with the $2^{\text {nd }}$ binding event. Evidence of this $2^{\text {nd }}$ event is not observed in Tris buffer a $\mathrm{pH} 8$, which may be due to $\mathrm{Cu}^{+}$-Tris interaction, as found with BCA and described above.

Using the best fits to the one-site model for comparison (Table 2), a significant difference in the binding enthalpy is found between the two buffers $\left(\Delta H_{\mathrm{obs} \text { (Tris) }}=-118.9 \pm 0.7\right.$ and $\Delta H_{\text {obs(HEPES) }}=-104 \pm 4 \mathrm{~kJ} \mathrm{~mol}^{-1}$ ). Unlike BCA, GSH binding to metal ions is necessarily coupled with a deprotonation at physiological $\mathrm{pH}$ due to coordination of the thiol $\left(\mathrm{p} K_{\mathrm{a}}=\right.$ 8.66). ${ }^{22}$ Therefore, a careful analysis of all equilibria that are coupled to the $\mathrm{GSH}-\mathrm{Cu}^{+}$ interaction is needed to account for the difference in net enthalpy. Scheme 2, in which $B$ represents the buffer and $x, y$, and $z$ are unknown or mixed stoichiometric coefficients associated with $\mathrm{Cu}^{+}-\mathrm{MeCN}$ species, identifies the major events that occur during this reaction.

The proton that is displaced from the GSH thiol $\left(\Delta H_{1}=-37 \mathrm{~kJ} \mathrm{~mol}^{-1}\right)^{22}$ will bind to the buffer, which generates heat from its protonation, $\Delta H_{3} ; 15,18,29$ because Tris and HEPES have different protonation enthalpies $\left(-47.5 \mathrm{~kJ} \mathrm{~mol}^{-1}\right.$ and $-21.4 \mathrm{~kJ} \mathrm{~mol}^{-1}$, respectively), $\Delta H_{\text {obs }}$ is expected to differ by this difference $\left(26.1 \mathrm{~kJ} \mathrm{~mol}^{-1}\right)$. However, subtracting $\Delta H_{3}$ from $\Delta H_{\text {obs }}$ yields $\Delta H_{\text {(HEPES })}=-82.6 \mathrm{~kJ} \mathrm{~mol}^{-1}$ and $\Delta H_{\text {(Tris) }}=-71.4 \mathrm{~kJ} \mathrm{~mol}^{-1}$. The difference between these two values $\left(\Delta \Delta H_{\text {(HEPES-Tris) }}=-11 \pm 4 \mathrm{~kJ} \mathrm{~mol}^{-1}\right)$ is very similar to the observed difference in enthalpy between these two buffers in the BCA titrations of $\mathrm{Cu}^{+}$. Since all other equilibria are expected to be identical under the two conditions, this difference is likely associated with an additional $\mathrm{Cu}^{+}-$Tris interaction $\left(\Delta H_{4}\right)$. 
The four-fold difference in $K_{1}$ between HEPES at pH $7.5\left(K_{1}=3.2 \times 10^{5}\right)$ and Tris at pH 8.0 $\left(K=1.3 \times 10^{6}\right)$ in Table 2 can be explained by the experimental $\mathrm{pH}$. The $\mathrm{p} K_{\mathrm{a}}$ of the GSH thiol (8.66) leads to a proton competition factor (eqn (4)) of $\alpha=6$ at pH 8.0 and $\alpha=15.5$ at $\mathrm{pH} 7.5$; accounting for this difference results in the very similar $\mathrm{pH}$-independent binding constants of $7 \times 10^{6}$ and $5 \times 10^{6}$, respectively.

Glutathione binding to $\mathrm{Cu}_{(}^{+}{ }_{(\mathrm{aq})}$-At $\mathrm{pH} 7.5$ in HEPES buffer there is calorimetric evidence for two GSH binding events, although the second is weak and characterized by large fit errors (Table 2). This low affinity event is not observed in Tris buffer at $\mathrm{pH}$ 8.0, which may be due to $\mathrm{Cu}^{+}-$Tris interaction discussed above. Accounting for buffer ionization, the $\mathrm{Cu}^{+}-\mathrm{GSH}$ interaction is characterized by a striking entropic penalty that lowers the binding free energy (ESI Table S3 $\dagger$ ). Similar results are found with $N$ acetylcysteine binding to $\mathrm{Cu}^{+}$(unpublished results). This affinity of GSH for $\mathrm{Cu}^{+}$is consistent with the observation that it does not compete with copper-binding proteins for $\mathrm{Cu}^{+}$in vitro. ${ }^{11,30,31}$

\section{Conclusions}

The unique chemical properties of $\mathrm{Cu}^{+}$provide experimental challenges to accurately quantify the thermodynamics of its binding to ligands, proteins and other biological molecules. This study has investigated and validated a method to prepare $\mathrm{Cu}^{+}$-stabilized complexes in aqueous solution for their use in binding measurements, specifically calorimetric measurements with ITC. The stability of these complexes varies over several orders of magnitude and their thermodynamics of formation have been determined (Table 3). This provides a set of well-characterized species for the delivery of $\mathrm{Cu}^{+}$and the accurate determination of $\mathrm{Cu}^{+}$binding thermodynamics with a wide range of biological ligands and protein sites. Two $\mathrm{Cu}^{+}$-stabilizing ligands are recommended from this work: $\mathrm{MeCN}$ and $\mathrm{Me}_{6}$ Trien. MeCN is attractive due to its low affinity and apparent "enthalpic silence". However, as found with the GSH experiments, it has the potential to form ternary complexes that can unknowingly compromise measurements of the thermodynamics of $\mathrm{Cu}^{+}$ interactions. As such, it should be used with caution, and only when sequential binding events are not desired and the final complex accounts for all of the coordination sites. $\mathrm{Me}_{6}$ Trien, on the other hand, forms a well-characterized $1: 1$ complex with intermediate stability that avoids this problem, although its stabilization of $\mathrm{Cu}^{+}$does depend on $\mathrm{pH}$.

\section{Supplementary Material}

Refer to Web version on PubMed Central for supplementary material.

\section{Acknowledgements}

We thank Jolene Schuster at Dartmouth College for valuable conversations and contributions to the experimental design, and George Lisi at Dartmouth College for collecting the EPR data.

Funding sources

This work was supported by the National Institute of General Medical Sciences (8 P20 GM103499), as well as Winthrop University startup funds, to NEG, and NSF grant CHE1308598 to DEW. 


\section{References}

1. Halloran TVO, Huffman DL. Annu. Rev. Biochem. 2001; 70:677-701. [PubMed: 11395420]

2. Rosenzweig, AC.; Lieberman, RL. Comprehensive Coordination Chemistry II. McCleverty, JA.; Meyer, TJ., editors. Pergamon; Oxford: 2003. p. 195-211.

3. Thiele DJ, Puig S. Curr. Opin. Chem. Biol. 2002; 6:171-180. [PubMed: 12039001]

4. Cotton, A.; Wilkinson, G.; Murillo, CA.; Bochman, M. Advanced Inorganic Chemistry. 6th edn. John Wiley and Sons; New York: 1999.

5. Liu T, Ramesh A, Ma Z, Ward SK, Zhang L, George GN, Talaat AM, Sacchettini JC, Giedroc DP. Nat. Chem. Biol. 2007; 3:60-68. [PubMed: 17143269]

6. Ma Z, Cowart DM, Scott RA, Giedroc DP. Biochemistry. 2009; 48:3325-3334. [PubMed: 19249860]

7. Grossoehme NE, Kehl-Fie TE, Ma Z, Adams KW, Cowart DM, Scott RA, Skaar EP, Giedroc DP. J. Biol. Chem. 2011; 286:13522-13531. [PubMed: 21339296]

8. Rae TD, Schmidt PJ, Pufahl RA, Culotta VC, O'Halloran TV. Science. 1999; 284:805-808. [PubMed: 10221913]

9. Xiao Z, Brose J, Schimo S, Ackland SM, La Fontaine S, Wedd AG. J. Biol. Chem. 2011; 286:11047-11055. [PubMed: 21258123]

10. Xiao Z, Donnelly PS, Zimmermann M, Wedd AG. Inorg. Chem. 2008; 47:4338-4347. [PubMed: $18412332]$

11. Xiao Z, Loughlin F, George GN, Howlett GJ, Wedd AG. J. Am. Chem. Soc. 2004; 126:30813090. [PubMed: 15012137]

12. Zimmermann M, Clarke O, Gulbis JM, Keizer DW, Jarvis RS, Cobbett CS, Hinds MG, Xiao Z, Wedd AG. Biochemistry. 2009; 48:11640-11654. [PubMed: 19883117]

13. Jelesarov I, Bosshard HR. J. Mol. Recognit. 1999; 12:3-18. [PubMed: 10398392]

14. Hansen LD, Fellingham GW, Russell DJ. Anal. Biochem. 2011; 409:220-229. [PubMed: 21073852]

15. Grossoehme NE, Spuches AM, Wilcox DE. J. Biol. Inorg. Chem. 2010; 15:1183-1191. [PubMed: 20725755]

16. Riddles, PW.; Blakeley, RL.; Zerner, B. Methods in Enzymology. Hirs, CHW.; Timasheff, SN., editors. Vol. 91. Academic Press; 1983. p. 49-60.

17. Zhao H, Piszczek G, Schuck P. Methods. 2015; 76:137-148. [PubMed: 25477226]

18. Grossoehme NE, Akilesh S, Guerinot ML, Wilcox DE. Inorg. Chem. 2006; 45:8500-8508. [PubMed: 17029360]

19. Grossoehme, NE.; Giedroc, DP. Fenton, AW., editor. Vol. 796. Humana Press; 2012. p. 31-51.

20. Kamau P, Jordan RB. Inorg. Chem. 2001; 40:3879-3883. [PubMed: 11466044]

21. Bagchi P, Morgan MT, Bacsa J, Fahrni CJ. J. Am. Chem. Soc. 2013; 135:18549-18559. [PubMed: 24298878]

22. Smith RM, Martell AE. Critical Stability Constants, NIST Standard Reference Database 46, Version 7.0. 2003

23. Gorelsky SI, Basumallick L, Vura-Weis J, Sarangi R, Hodgson KO, Hedman B, Fujisawa K, Solomon EI. Inorg. Chem. 2005; 44:4947-4960. [PubMed: 15998022]

24. Smith GF, Wilkins DH. Anal. Chem. 1953; 25:510-511.

25. Blair D, Diehl H. Talanta. 1961; 7:163-174.

26. Navon N, Golub G, Cohen H, Paoletti P, Valtancoli B, Bencini A, Meyerstein D. Inorg. Chem. 1999; 38:3484-3488. [PubMed: 11671093]

27. Golub G, Cohen H, Paoletti P, Bencini A, Messori L, Bertini I, Meyerstein D. J. Am. Chem. Soc. 1995; 117:8353-8361.

28. Banci L, Bertini I, Ciofi-Baffoni S, Kozyreva T, Zovo K, Palumaa P. Nature. 2010; 465:645-648. [PubMed: 20463663]

29. Baker BM, Murphy KP. Biophys. J. 1996; 71:2049-2055. [PubMed: 8889179]

30. Huffman DL, Halloran TVO. J. Biol. Chem. 2000; 275:18611-18614. [PubMed: 10764731] 
31. Ralle M, Lutsenko S, Blackburn NJ. J. Biol. Chem. 2003; 278:23163-23170. [PubMed: 12686548] 

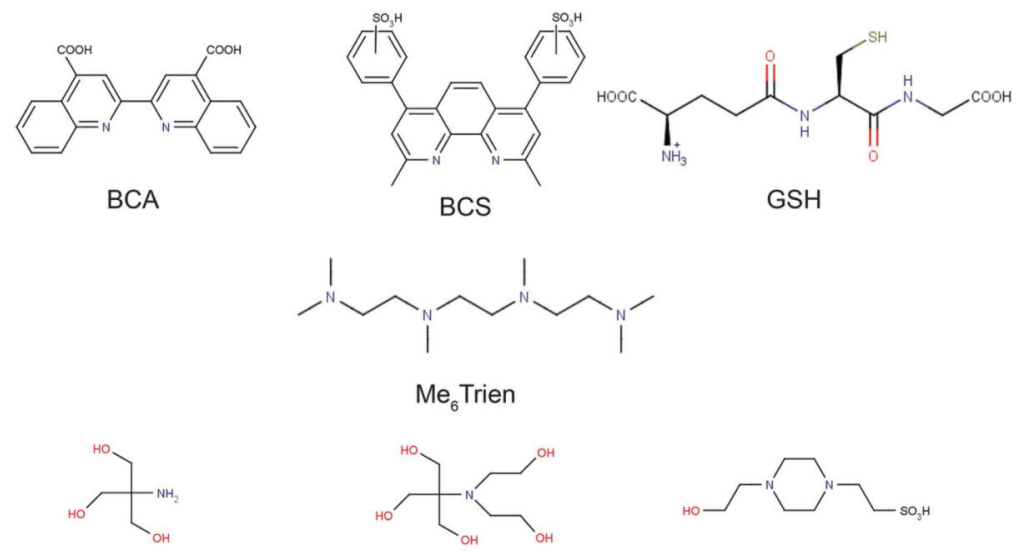

Tris

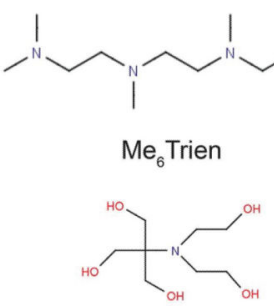

Bis-tris

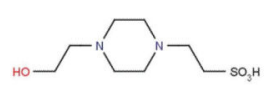

HEPES

Fig. 1.

Ligands and buffers used in this study. 

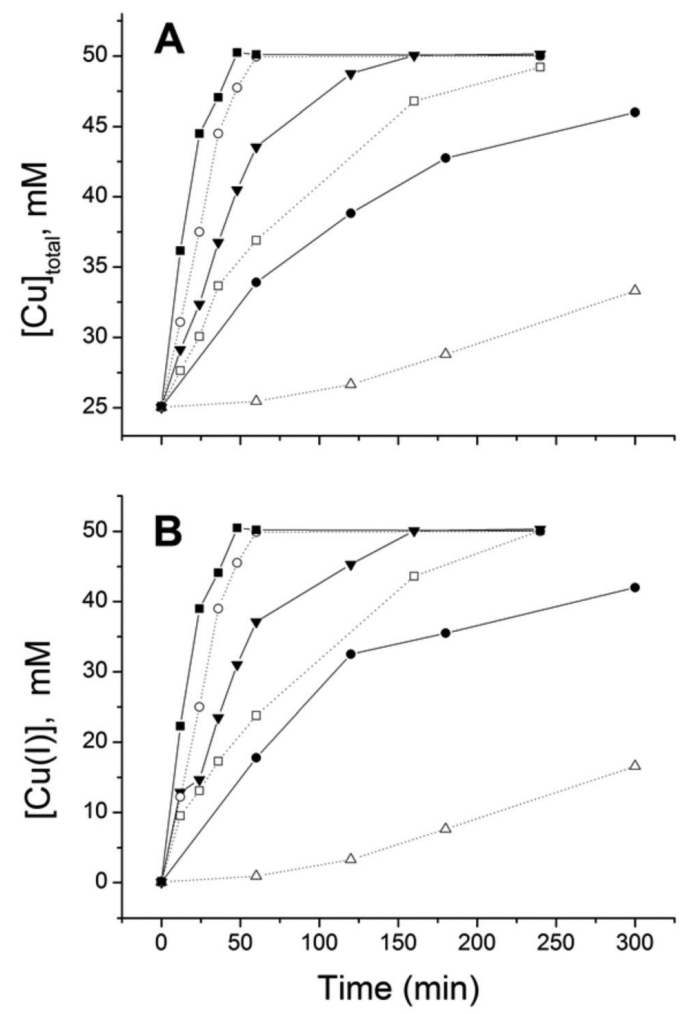

Fig. 2.

Progress of the comproportionation reaction of copper wire and $25.00 \mathrm{mM} \mathrm{CuCl} 2$ in $\mathrm{MeCN}$ monitored by (A) total soluble copper by AAS and (B) $\left[\mathrm{Cu}^{+}\right]$by the BCA assay, described

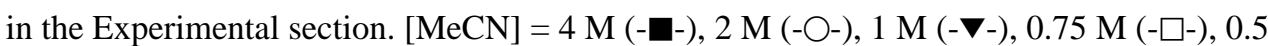
(-) $)$ or $0.25 \mathrm{M}(-\triangle-)$. 


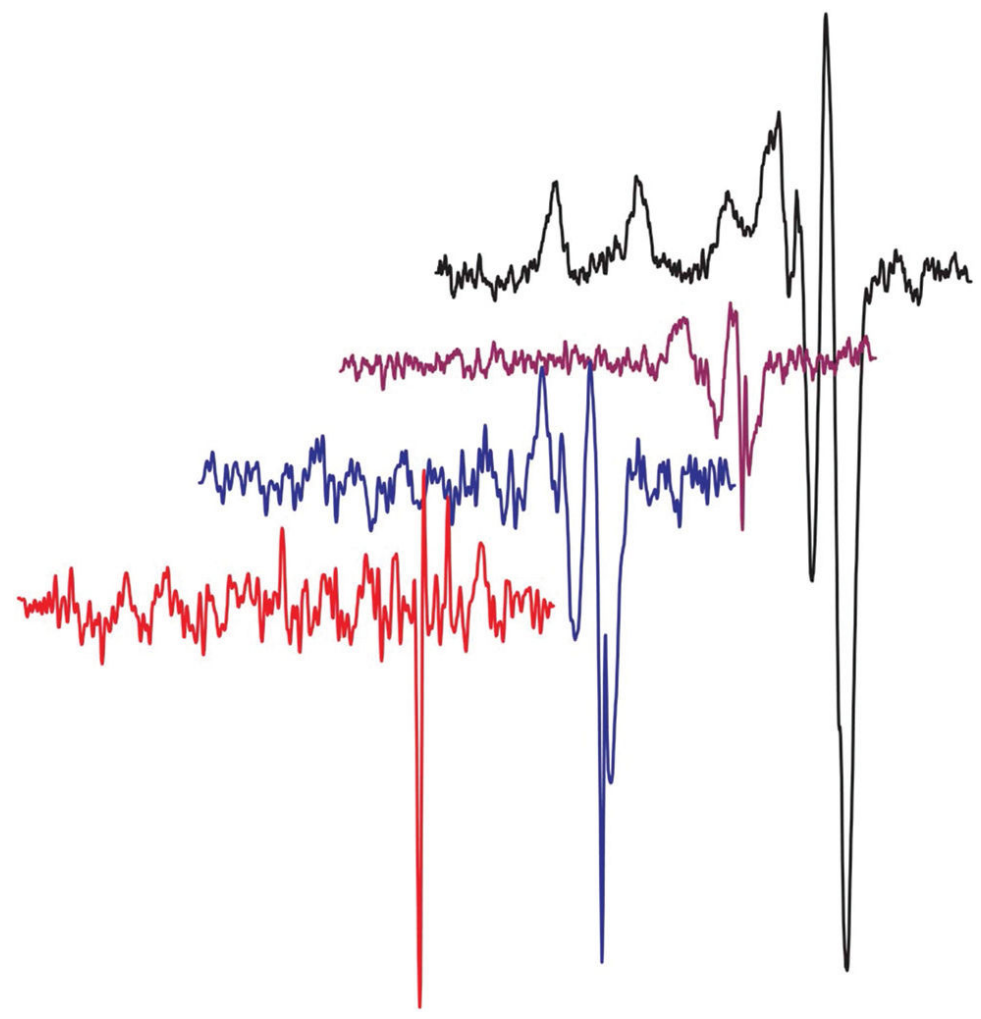

Fig. 3.

The $77 \mathrm{~K}$ EPR spectra (offset for clarity) of $12.5 \mu \mathrm{M}$ (black line; $g_{\|}=2.22, A_{\|}=196 \mathrm{G}, g_{\perp}$ $=2.01$ ) and $1.25 \mu \mathrm{M}$ (purple line) $\mathrm{Cu}^{2+}$ standards, and $125 \mu \mathrm{M} \mathrm{Cu}^{+}$prepared by diluting the $50 \mathrm{mM} \mathrm{Cu}^{+}$comproportionation stock solution in $5 \mathrm{mM}$ (blue line) or $25 \mathrm{mM}$ (red line, gain $\times 10) \mathrm{MeCN}$. 

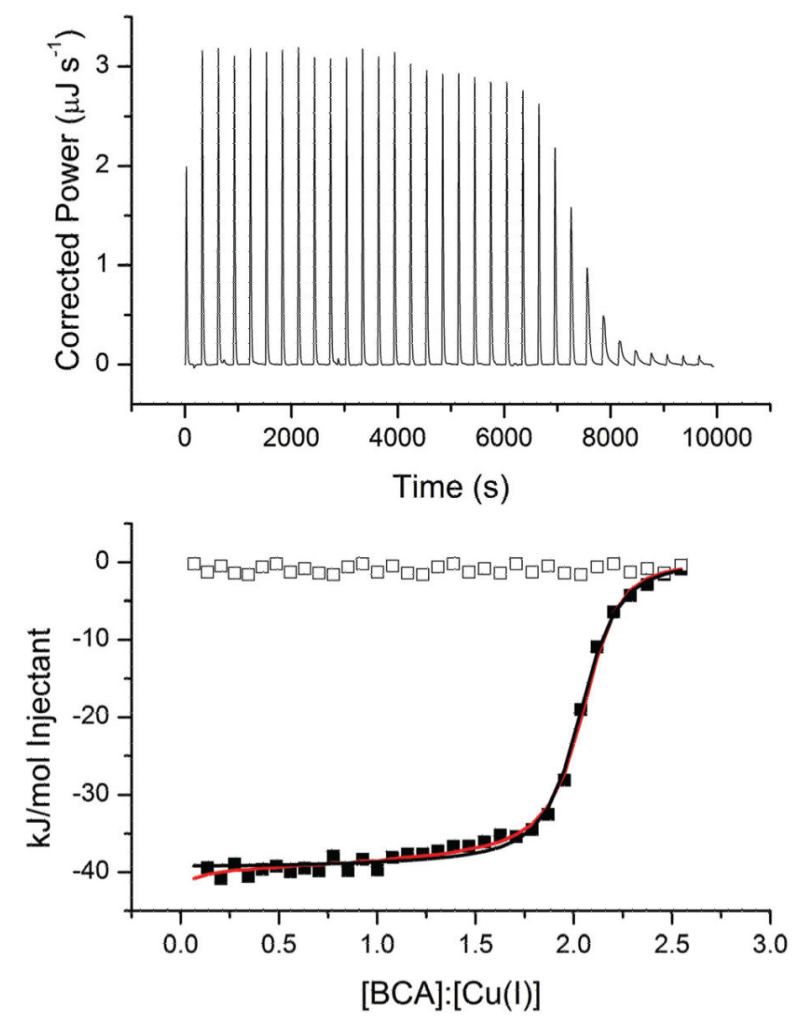

Fig. 4.

Representative ITC titration of $1.0 \mathrm{mM} \mathrm{BCA}$ into $125 \mu \mathrm{M} \mathrm{Cu}^{+}$in $25 \mathrm{mM}$ HEPES, $100 \mathrm{mM}$ $\mathrm{NaCl}$ and $25 \mathrm{mM} \mathrm{MeCN}$ at pH 7.0 on a TA Instruments Nano ITC. The black line indicates the best fit using a one-site binding model $\left(n=2.01 \pm 0.06, K=1.7 \pm 0.2 \times 10^{6}, \Delta H=-37.3\right.$ $\left.\pm 0.2 \mathrm{~kJ} \mathrm{~mol}^{-1}, \mathrm{RSS} / \mathrm{DoF}=7.71\right)$ and the red line represents the best fit using a sequential binding model $\left(K_{1}=8.9 \pm 0.7 \times 10^{5}, \Delta H_{1}=-42.0 \pm 0.2 \mathrm{~kJ} \mathrm{~mol}^{-1}, K_{2}=1.1 \pm 0.1 \times 10^{6}, \Delta H_{2}\right.$ $\left.=-36 \pm 1 \mathrm{~kJ} \mathrm{~mol}^{-1}, \mathrm{RSS} / \mathrm{DoF}=4.07\right)$. Open boxes indicate the heat of BCA dilution. 


$$
\begin{array}{lc}
\mathrm{Cu}^{\mathrm{I}}(\mathrm{BCA})_{2}{ }^{3-} \rightleftharpoons \mathrm{Cu}^{\mathrm{I}}(\mathrm{BCA})_{1}{ }^{1-}+\mathrm{BCA}^{2-} & \Delta \mathrm{H}=-\Delta \mathrm{H}_{\mathrm{CuBCA}} \\
\left.\underline{\mathrm{Cu}^{\mathrm{I}}+\mathrm{BCA}^{2-} \rightleftharpoons \mathrm{Cu}^{\mathrm{I}}(\mathrm{BCA})}\right)_{1}{ }^{1-} & \Delta \mathrm{H}=\Delta \mathrm{H}_{\mathrm{CuBCA}} \\
\mathrm{Cu}^{\mathrm{I}}(\mathrm{BCA})_{2}{ }^{3-}+\mathrm{Cu}^{\mathrm{I}} \rightleftharpoons 2 \mathrm{Cu}^{\mathrm{I}}(\mathrm{BCA})_{1}{ }^{1-} & \Delta \mathrm{H}_{\mathrm{obs}}=0
\end{array}
$$

Scheme 1.

Equilibria for the second step of the reverse titration. 

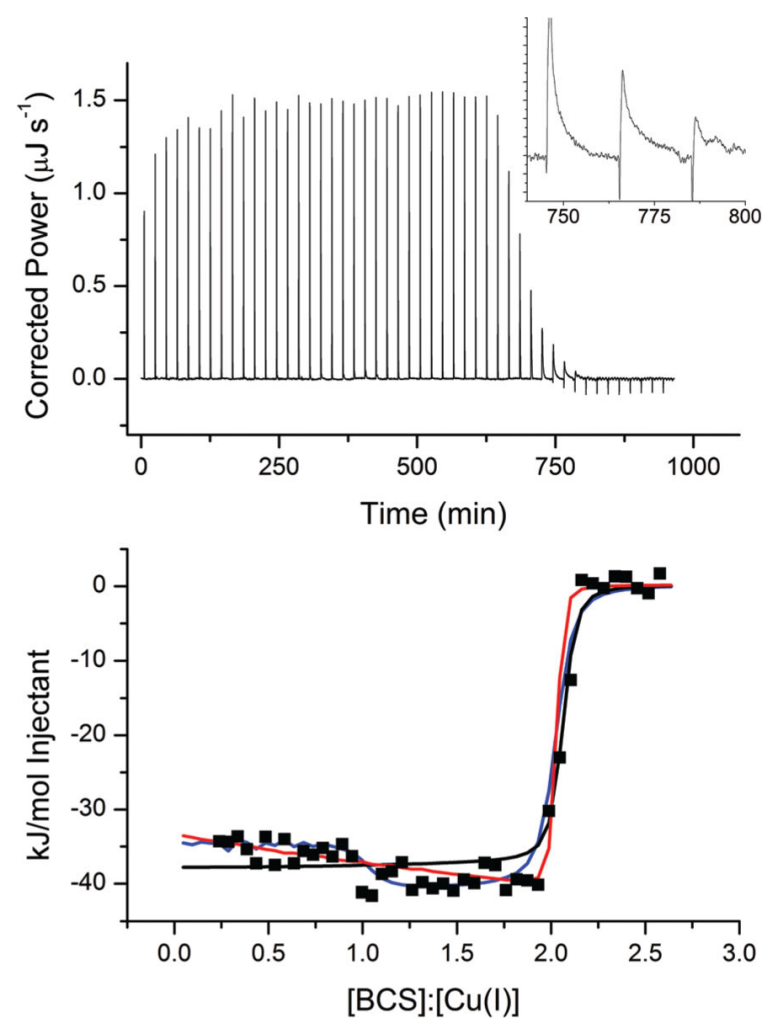

Fig. 5.

Representative ITC titration of $1.0 \mathrm{mM}$ BCS into $125 \mu \mathrm{M} \mathrm{Cu}^{+}$in $25 \mathrm{mM}$ Tris, $100 \mathrm{mM}$ $\mathrm{NaCl}$ and $25 \mathrm{mM} \mathrm{MeCN}$ at $\mathrm{pH} 8.0$ on a TA Instruments Nano ITC. The solid black line indicates the best fit using a one-site binding model $\left(n=2.03 \pm 0.01, \mathrm{~K}=1.8 \pm 0.9 \times 10^{7}\right.$, $\left.\Delta H=-37.9 \pm 0.4 \mathrm{~kJ} \mathrm{~mol}^{-1}, \mathrm{RSS} / \mathrm{DoF}=157\right)$ and the blue and red lines represent two independent fits using a sequential binding model (Blue: $K_{1}=1.5 \pm 0.1 \times 10^{9}, \Delta H_{1}=-34.7$ $\pm 0.5 \mathrm{~kJ} \mathrm{~mol}^{-1}, K_{2}=4.75 \pm 0.4 \times 10^{6}, \Delta H_{2}=-41.2 \pm 0.6 \mathrm{~kJ} \mathrm{~mol}^{-1}, \mathrm{RSS} / \mathrm{DoF}=50.5 ; \mathrm{Red}$ : $K_{1}=1.5 \pm 0.6 \times 10^{8}, \Delta H_{1}=-33 \pm 1 \mathrm{~kJ} \mathrm{~mol}^{-1}, K_{2}=4 \pm 1 \times 10^{7}, \Delta H_{2}=-42 \pm 1 \mathrm{~kJ} \mathrm{~mol}^{-1}$, $\mathrm{RSS} / \mathrm{DoF}=67.75$ ). The insert shows an expansion of the last three exothermic injections. 


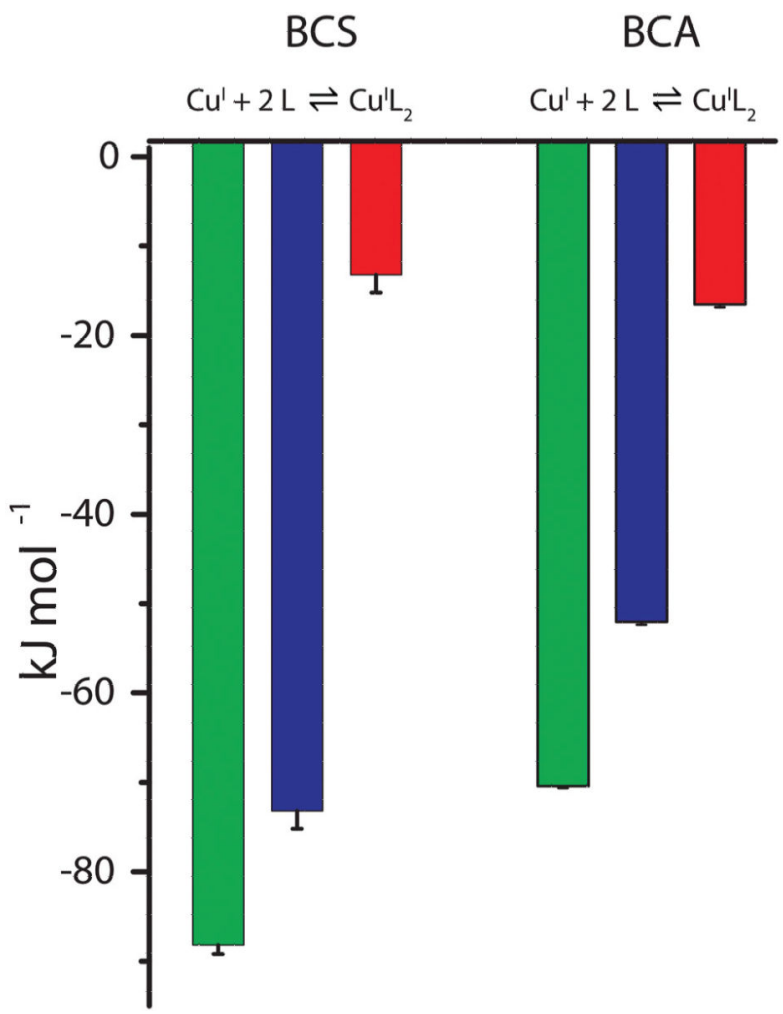

Fig. 6.

Thermodynamic profile for ligand binding to $\mathrm{Cu}^{+}$at $\mathrm{pH} 8.0$ in $25 \mathrm{mM} \mathrm{MeCN}$ and $100 \mathrm{mM}$ $\mathrm{NaCl}$. Green $=\Delta G$, blue $=\Delta H$, red $=-T \Delta S$. BCS: $\Delta G=-90 \pm 1, \Delta H=-75 \pm 2,-T \Delta S=-15$ \pm 2 ; BCA: $\Delta G=-72 \pm 1, \Delta H=-54.0 \pm 0.3,-T \Delta S=-18.0 \pm 0.4$. 
A

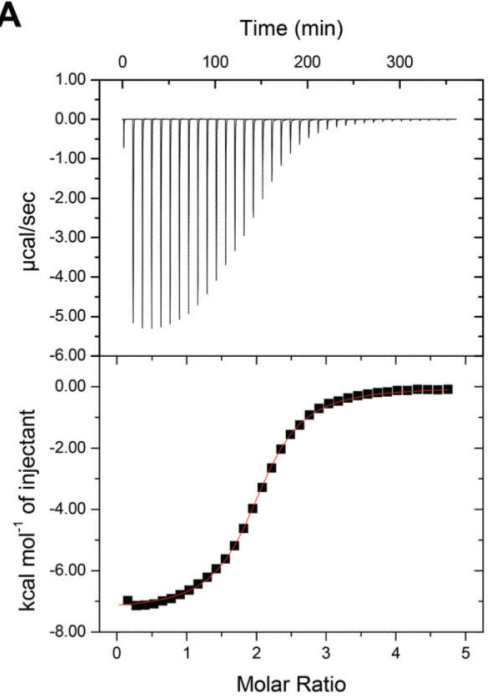

B

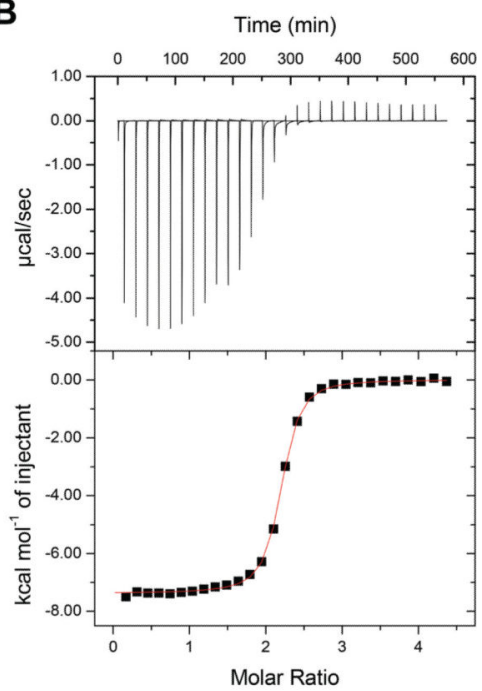

Fig. 7.

Representative ITC titrations of (A) $2.5 \mathrm{mM} \mathrm{BCA}$ and (B) $2.0 \mathrm{mM} \mathrm{BCS}$ into $100 \mu \mathrm{M} \mathrm{Cu}^{+}$in $50 \mathrm{mM}$ HEPES, $50 \mathrm{mM} \mathrm{NaCl}, 5 \mathrm{mM} \mathrm{Me}_{6}$ Trien, $\mathrm{pH} 7.4$ on a MicroCal VP-ITC. Best fits to the data with a one-site binding model are: (A) $n=2.01 \pm 0.01, K=1.53 \pm 0.04 \times 10^{5}, \Delta H=$ $-7.39 \pm 0.02 \mathrm{kcal} \mathrm{mol}^{-1}$ and (B) $n=2.14 \pm 0.01, K=1.55 \pm 0.06 \times 10^{6}, \Delta H=-7.36 \pm 0.04$ $\mathrm{kcal} \mathrm{mol}^{-1}$. 


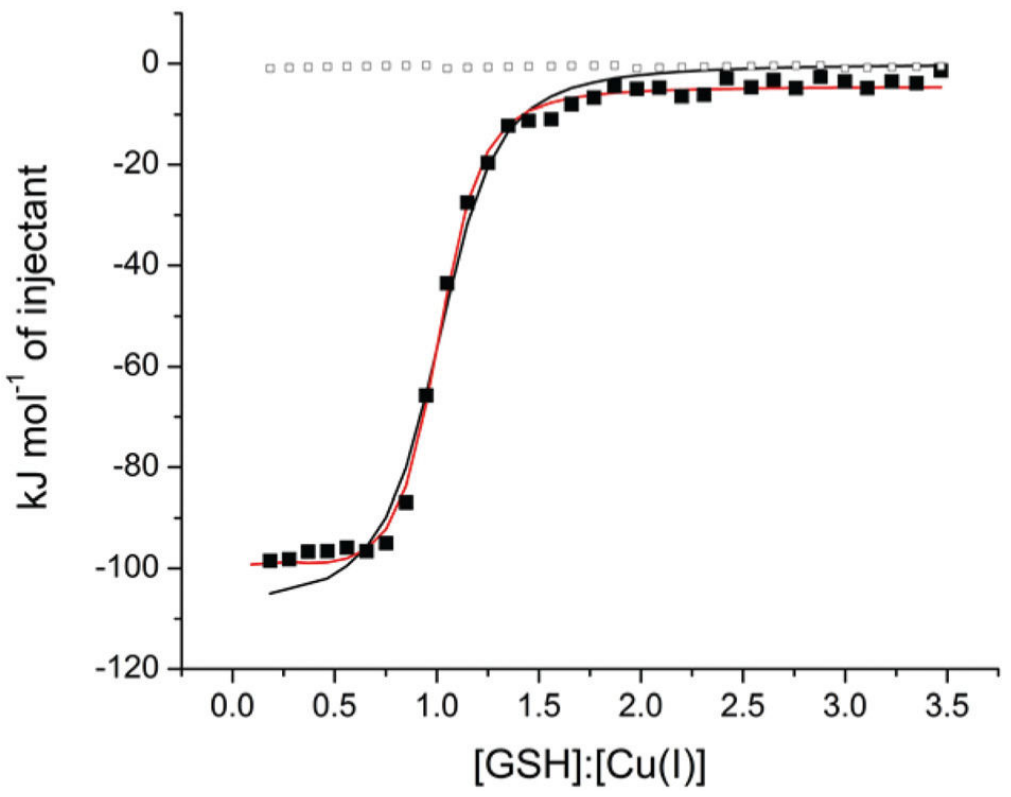

Fig. 8.

Integrated intensity of a representative ITC titration of $1.73 \mathrm{mM} \mathrm{GSH}$ into $168 \mu \mathrm{M} \mathrm{Cu} \mathrm{u}^{+}$in $25 \mathrm{mM}$ HEPES, $100 \mathrm{mM} \mathrm{NaCl}$ and $25 \mathrm{mM} \mathrm{MeCN}$ at $\mathrm{pH} 7.5$ on a TA Instruments Nano ITC. The solid black line indicates the best fit using a one-site binding model $(n=0.98 \pm$ $\left.0.02, K=2.9 \pm 0.1 \times 10^{5}, \Delta H=-108 \pm 6 \mathrm{~kJ} \mathrm{~mol}^{-1}, \mathrm{RSS} / \mathrm{DoF}=158.3\right)$ and the red line represents the best fit using a sequential binding model $\left(K_{1}=6 \pm 5 \times 10^{5}, \Delta H_{1}=-101 \pm 3\right.$ $\left.\mathrm{kJ} \mathrm{mol}^{-1}, K_{2}=1 \pm 8 \times 10^{3}, \Delta H_{2}=-10 \pm 10 \mathrm{~kJ} \mathrm{~mol}^{-1}, \mathrm{RSS} / \mathrm{DoF}=23.5\right)$. Open boxes indicate the heat of GSH dilution. 


$\begin{array}{cr}\mathrm{GSH} \rightleftharpoons \mathrm{GS}^{-}+\mathrm{H}^{+} & \Delta \mathrm{H}_{1} \\ \mathrm{GS}^{-}+\mathrm{Cu}^{\mathrm{I}}(\mathrm{MeCN})_{\mathrm{x}} \rightleftharpoons \mathrm{Cu}^{\mathrm{I}}\left(\mathrm{GS}^{-}\right)(\mathrm{MeCN})_{\mathrm{y}}+(\mathrm{x}-\mathrm{y}) \mathrm{MeCN} & \Delta \mathrm{H}_{2} \\ \mathrm{H}^{+}+\mathrm{B} \rightleftharpoons \mathrm{HB} & \Delta \mathrm{H}_{3} \\ \mathrm{Cu}^{\mathrm{I}}(\mathrm{MeCN})_{2} \cdot \mathrm{B}+\rightleftharpoons \mathrm{Cu}^{\mathrm{I}}(\mathrm{MeCN})_{x}+\mathrm{B} & \Delta \mathrm{H}_{4} \\ \mathrm{GSH}+\mathrm{Cu}^{\mathrm{I}}(\mathrm{MeCN})_{\mathrm{z}}+\mathrm{B} \rightleftharpoons \mathrm{Cu}^{\mathrm{I}}\left(\mathrm{GS}^{-}\right)(\mathrm{MeCN})_{\mathrm{y}}+(\mathrm{x}-\mathrm{y}) \mathrm{MeCN}+\mathrm{HB} & \Delta \mathrm{H}_{\mathrm{Obs}}\end{array}$

Scheme 2.

Equilibria associated with $\mathrm{MeCN}$-stabilized $\mathrm{Cu}^{+}$binding to $\mathrm{GSH}$. 
Table 1

Average best fits of ITC experimental data for $\mathrm{BCA} / \mathrm{Cu}^{+}$titrations at $25^{\circ} \mathrm{C}$ to a one-site binding model ${ }^{a}$

\begin{tabular}{|c|c|c|c|c|c|}
\hline Buffer & pH & {$[\mathrm{MeCN}](\mathbf{m M})$} & $n$ & $\Delta H \mathrm{~kJ} \mathrm{~mol}^{-1}\left(\mathrm{kcal} \mathrm{mol}^{-1}\right)$ & $K_{\text {ITC }}\left(\times 10^{6}\right)$ \\
\hline \multicolumn{6}{|c|}{$\mathrm{BCA} \rightarrow \mathrm{Cu}^{\mathrm{I}}$} \\
\hline Tris & 7.5 & 25 & $2.11 \pm 0.05$ & $-28 \pm 1(-6.7 \pm 0.2)$ & $2.2 \pm 0.2$ \\
\hline Tris & 8.0 & $10^{b}$ & $1.96 \pm 0.04$ & $-27.3 \pm 0.8(-6.5 \pm 0.2)$ & $2.3 \pm 0.3$ \\
\hline Tris & 8.0 & 25 & $2.02 \pm 0.01$ & $-27.0 \pm 0.2(-6.45 \pm 0.05)$ & $2.0 \pm 0.3$ \\
\hline Tris & 8.0 & 500 & $1.9 \pm 0.1$ & $-28 \pm 1(-6.7 \pm 0.2)$ & $3.6 \pm 0.3$ \\
\hline Tris & 8.0 & 1000 & $2.01 \pm 0.09$ & $-27.1 \pm 0.7(-6.5 \pm 0.1)$ & $1.1 \pm 0.1$ \\
\hline Tris & 8.5 & 25 & $1.98 \pm 0.03$ & $-27.0 \pm 0.5(-6.5 \pm 0.1)$ & $0.8 \pm 0.1$ \\
\hline Bis-Tris & 6.0 & 25 & $2.04 \pm 0.01$ & $-38.0 \pm 0.2(-9.09 \pm 0.05)$ & $2.4 \pm 0.1$ \\
\hline Bis-Tris & 7.0 & 25 & $1.95 \pm 0.01$ & $-37.0 \pm 0.4(-8.84 \pm 0.09)$ & $2.3 \pm 0.5$ \\
\hline HEPES & 7.0 & 25 & $2.08 \pm 0.01$ & $-37.0 \pm 0.5(-8.8 \pm 0.1)$ & $2.4 \pm 0.4$ \\
\hline \multicolumn{6}{|c|}{$\mathrm{Cu}^{\mathrm{I}} \rightarrow \mathrm{BCA}$} \\
\hline Tris & 8.0 & 500 & $0.51 \pm 0.01$ & $-53.2 \pm 0.2(-12.81 \pm 0.05)$ & $2 \pm 3$ \\
\hline HEPES & 7.0 & 500 & $0.48 \pm 0.01$ & $-72.4 \pm 0.5(-13.3 \pm 0.1)$ & $5 \pm 3$ \\
\hline
\end{tabular}


Table 2

Average best fits of ITC experimental data for ligand $\rightarrow \mathrm{Cu}^{+}$titrations at $25{ }^{\circ} \mathrm{C}^{a}$

\begin{tabular}{|c|c|c|c|c|c|c|}
\hline Ligand & Model & $n_{1}$ & $\Delta H_{1} \mathrm{~kJ} \mathrm{~mol}^{-1}\left(\mathrm{kcal} \mathrm{mol}^{-1}\right)$ & $K_{1}\left(\times 10^{6}\right)$ & $\Delta \mathrm{H}_{2} \mathrm{~kJ} \mathrm{~mol}^{-1}\left(\mathrm{kcal} \mathrm{mol}^{-1}\right)$ & $K_{2}\left(\times 10^{6}\right)$ \\
\hline \multicolumn{7}{|c|}{$25 \mathrm{mM}$ Tris $\mathrm{pH} 8.0$} \\
\hline $\mathrm{BCS}$ & One site & $2.11 \pm 0.05$ & $-37 \pm 1(-8.84 \pm 0.02)$ & $22 \pm 2$ & & \\
\hline BCS & Sequential & - & $-33 \pm 1(-7.9 \pm 0.2)$ & $150 \pm 60$ & $-42 \pm 2(-10.0 \pm 0.5)$ & $40 \pm 1$ \\
\hline GSH & One site & $1.03 \pm 0.3$ & $-118.9 \pm 0.7(-28.4 \pm 0.2)$ & $1.3 \pm 0.1$ & & \\
\hline \multicolumn{7}{|c|}{25 mM HEPES pH 7.5} \\
\hline GSH & One site & $0.99 \pm 0.01$ & $-104 \pm 4(-24.9 \pm 0.9)$ & $0.32 \pm 0.08$ & & \\
\hline GSH & Sequential & - & $-98 \pm 2(-23 \pm 1)$ & $0.3 \pm 0.2$ & $-6 \pm 20(-1 \pm 5)$ & $0.001 \pm 0.001$ \\
\hline
\end{tabular}

${ }^{a}$ All data collected in $100 \mathrm{mM} \mathrm{NaCl}$ and $25 \mathrm{mM} \mathrm{MeCN}$. Fit parameters represent the average of at least two independent titrations. Error is calculated by propagation of individual fits; see Experimental for explanation. 
Table 3

Condition-independent $\mathrm{Cu}^{+}$stability constants and formation enthalpies at $25^{\circ} \mathrm{C}$

\begin{tabular}{|c|c|c|c|c|c|}
\hline Ligand & $n$ & $\beta_{n}$ & $\log \beta_{n}$ & $\log \beta_{n}$ (literature) & $\Delta H_{\mathrm{CU}(\mathrm{I}) \mathrm{L}}\left(\mathrm{kJ} \mathrm{mol}^{-1}\right)$ \\
\hline $\mathrm{Me}_{6}$ Trien & 1 & $3 \pm 1 \times 10^{12}$ & 12.4 & $11^{b}$ & $-17 \pm 8$ \\
\hline $\mathrm{BCA}^{a}$ & 2 & & 17.6 & $17.5^{c}$ & $-75 \pm 0.3$ \\
\hline BCS & 2 & $4 \pm 1 \times 10^{20}$ & 20.6 & $20.4^{c}$ & $-95 \pm 2$ \\
\hline \multicolumn{6}{|c|}{$\beta_{n}$ for BCA was used as a reference value. } \\
\hline \multicolumn{6}{|c|}{${ }^{b}$ Literature value from Navon et al. ${ }^{26}$} \\
\hline
\end{tabular}


Table 4

Average best fits of ITC experimental data for ligand $\rightarrow \mathrm{Cu}^{\mathrm{I}} \mathrm{Me}_{6} \operatorname{Trien}^{+}$at $25{ }^{\circ} \mathrm{C}^{a}$

\begin{tabular}{|c|c|c|c|c|}
\hline Ligand & $n_{1}$ & $\Delta H_{1} \mathrm{~kJ} \mathrm{~mol}^{-1}\left(\mathrm{kcal} \mathrm{mol}^{-1}\right)$ & $K_{1}\left(\times 10^{6}\right)$ & $\log _{\mathrm{CuMe}_{6} \text { Trien }^{+}}{ }^{b}$ \\
\hline $\mathrm{BCA}$ & $1.92 \pm 0.04$ & $-30 \pm 2(-7.1 \pm 0.4)$ & $0.17 \pm 0.04$ & $12.1 \pm 0.2$ \\
\hline $\mathrm{BCS}$ & $2.12 \pm 0.03$ & $-31 \pm 1(-7.4 \pm 0.3)$ & $1.3 \pm 0.8$ & $12.8 \pm 0.6$ \\
\hline
\end{tabular}

